\title{
Agricultural intensification and policy interventions: Exploring plausible futures for smallholder farmers in Southern Mali
}

\author{
Gatien N. Falconnier $^{\mathrm{a}, *}$, Katrien Descheemaeker ${ }^{\mathrm{b}}$, Bouba Traore ${ }^{\mathrm{c}}$, Arouna Bayoko ${ }^{\mathrm{d}}$, Ken E. Giller ${ }^{\mathrm{b}}$ \\ a UMR AGIR, Université de Toulouse, INPT, INP-PURPAN, INRA, 31320 Castanet Tolosan, France \\ b Plant Production Systems, Wageningen University, P.O. Box 430, 6700 AK Wageningen, The Netherlands \\ c International Crops Research Institute for the Semi-Arid Tropics (ICRISAT-Mali), BP 320 Bamako, Mali \\ d Association Malienne d'Eveil au Developpement Durable (AMEDD), Darsalam II, Route de Ségou, BP 212 Koutiala, Mali
}

\section{A R T I C L E I N F O}

\section{Keywords:}

Farm typology

Yield gap

Rural-urban migration

Net fertility

\begin{abstract}
A B S T R A C T
Assessing how livelihoods in rural sub-Saharan Africa might change given future trends in socio-economic and biophysical conditions helps to identify and direct effective efforts towards poverty reduction. Based on existing literature, hypothetical changes in farmer practices and policy interventions were described and used to build five contrasting scenarios towards the year 2027. A simulation framework was developed to assess food selfsufficiency and income per capita now and in the future for a representative village of 99 households in Southern

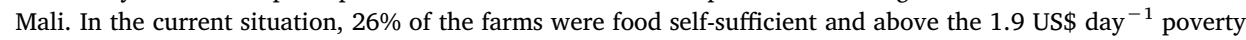
line. This percentage would fall to $13 \%$ in the "Business as usual" scenario. In the "Dairy development" scenario, with intensification of livestock production and support to the milk sector, $27 \%$ of farms would be food selfsufficient and non-poor. Additional policy interventions targeting family planning and job creation outside agriculture would be needed to improve both household food self-sufficiency and income per capita. In this optimistic scenario, $77 \%$ of the farms would be non-poor and food self-sufficient in 2027. Additional programs to promote Integrated Pest Management, small-scale mechanization and mineral fertilizer on traditional cereals could allow a drastic increase in productivity and would lift $94 \%$ of the farm population out of poverty. Considering the entire heterogeneous farm population was crucial to accurately assess pathways out of poverty. Our study stresses the need for a strategic and multi-sectoral combination of interventions to improve livelihoods.
\end{abstract}

\section{Introduction}

The human population in Africa is growing faster than in other continents and will account for more than half of the growth in the world's population between now and 2050 (United Nations, 2015). In many regions across sub-Saharan Africa there is no land suitable for further agricultural expansion, therefore farm size is decreasing (Harris and Orr, 2014). Faced with land shortage and the challenge to produce sufficient food, farmers can respond in three ways: intensifying agricultural production, migrating out of agriculture and/or reducing human fertility rates (Headey and Jayne, 2014). Policy interventions can favour these strategies, as examples from around Africa illustrate: large scale agricultural input subsidy programs improved land productivity in Malawi (Dorward and Chirwa, 2011). Educational investment targeting rural areas and creation of non-agricultural wage jobs in the cities favoured rural-urban migration in Uganda (de Brauw et al., 2014; Fox and Sohnesen, 2012). In Rwanda and Kenya, subsidized contraceptive services and education campaigns triggered the transition from high to low birth rates (Bongaarts, 2011). Yet the pace and the magnitude of the effects of such policy interventions are difficult to foresee (Thompson and Scoones, 2009). In Mali, achieving food selfsufficiency and poverty reduction are the key objectives of the latest "Loi d'Orientation Agricole" (LOA) (http://www.pcda-mali.org/site/ index.php/29-mediatheque/31-la-loi-D-orientation-agricole-du-maliloa, last accessed 19/02/2016). Hence assessing how income and food production might change under uncertain future socio-economic and biophysical conditions may generate useful information for directing policy interventions towards poverty reduction.

Scenarios help to capture uncertainty by defining plausible futures covering a range of socioeconomic and biophysical conditions (O'Neill et al., 2017). Many studies built scenarios based on hypothetical changes in population, policy interventions and efficiency of institutions and assessed their effect on land use change, intensification and diversification of agriculture (Enfors et al., 2008; Stephenne and

\footnotetext{
* Corresponding author.

E-mail addresses: ffalconniergatien@yahoo.fr, gatien.falconnier@inra.fr (G.N. Falconnier).
} 
Lambin, 2004). These studies illustrated how scenarios inform decisionmaking and help to target agricultural development investments. Some of these studies stressed the importance of considering farm heterogeneity to increase the assessment accuracy (García-Martínez et al., 2011; Gibreel et al., 2014; Herrero et al., 2014). However, they focused on land use change and did not quantify changes in food production and income for the different farm types. Scenario work is widespread for developed countries (Bizikova et al., 2015) but remains rare in subSaharan Africa, with scarce quantitative information on likely changes in income and food self-sufficiency. Furthermore, beyond future changes in representative farms or farm types, only few studies assess changes in entire diverse farm populations (Descheemaeker et al., 2016; Paul et al., 2017; Ritzema et al., 2017).

The "old cotton basin" in Southern Mali experiences fast population growth and increasing land shortage (Soumaré et al., 2008), common challenges in land constrained regions across sub-Saharan Africa. The region has shown a promising agricultural intensification pathway (1960-2000) linked to cotton production (Benjaminsen et al., 2010), but since the cotton crisis (2004), agricultural productivity has stagnated (Falconnier et al., 2015). Hence the Malian government is committed to increasing agricultural productivity (de la Croix et al., 2011; Kelly et al., 2011) and increasing off-farm opportunities for the youth (African Development Bank, 2012). Yet policy makers need locally grounded information to take effective decisions. Adding to the uncertainty of future trajectories of change, the heterogeneous farms of the region (Falconnier et al., 2015) are expected to respond differently to changes in socio-economic conditions.

The objective of this study was to assess the effects of agricultural intensification, rural to urban migration and net fertility reduction on rural poverty and food self-sufficiency for contrasting plausible midterm futures (fifteen years ahead) for the entire population of a case study village in the "old cotton basin" of Southern Mali. Specific objectives were to (i) build scenarios that span a wide range of uncertainty in socio-economic futures, (ii) develop a simulation framework that accounts for household demographic dynamics, sensitivity of crops to rainfall variability and change in farmer practices and (iii) assess trends in food self-sufficiency and income per capita for all farms in the village population in the different scenarios.

\section{Methods}

\subsection{Study area}

The "old cotton basin" is an area situated in the Sudanian agroecological zone of Southern Mali (Coulibaly, 2003). The rainy season starts in May and ends in October and total rainfall fluctuates from 500 to $1200 \mathrm{~mm}$. The area groups three districts (Koutiala, Dioila and the northern part of Sikasso) and accommodates more than a million of rural people (Traore et al., 2011). Households are extended families comprising the head of the household, his sons and wives and their children (Jonckers and Colleyn, 1974). Farmers grow cotton, cereals and groundnut in rotation and use manure, mineral fertilizer and oxen for draught power. The Compagnie Malienne pour le Developpement des Textiles (CMDT) buys the cotton and provides credit for mineral fertilizer for cotton and maize (Falconnier et al., 2015).

\subsection{Datasets}

The "Suivi Evaluation Permanent" (SEP) dataset collected by the "Equipe Système de Production et Gestion des Resources Naturelles (ESPGRN)" of the Malian Institut d'Economie Rural (IER) contains information on household resource endowment, input use and cotton yields measured by CMDT for 30 farms from three villages of the "old cotton basin" from 1994 to 2010. Farms were classified in four farm types, namely High Resource Endowed with Large Herds (HRE-LH), High Resource Endowed (HRE), Medium Resource Endowed (MRE) and
Low Resource Endowed (LRE) farms according to (1) total cropped land (ha), (2) number of workers, (3) herd size and (4) number of draught tools (Falconnier et al., 2015). LRE farmers usually don't have a full span of oxen and/or a plough.

Data on resource endowment and crop area in 2013 for the 99 households of the Nampossela village $\left(12^{\circ} 15^{\prime} \mathrm{N}\right.$ and $\left.15^{\circ} 20^{\prime} \mathrm{W}\right)$ was obtained from the CMDT. All households in Nampossela were classified in one of the four HRE-LH, HRE, MRE and LRE farm types. Nampossela is a typical village of the 'old cotton basin'. It is close $(10 \mathrm{~km})$ to the three SEP villages where the farm typology was generated, with very similar agro-ecology, farm practices and marketing opportunities. The share of the four farm types in this village was $12 \%, 19 \%, 55 \%$ and $14 \%$ for HRE-LH, HRE, MRE, LRE farms respectively, which is close to the average share in the Koutiala region (Falconnier et al., 2015).

\subsection{Scenario building}

Starting from the baseline year 2013, we explored the effects of wide-ranging future agricultural and socio-economic changes within a 15-year time span (2013-2027). Hypothetical trends in agricultural intensification were conceived based on promising agricultural technologies identified for the region. On the policy side, we took into account expected changes in the cotton and milk context described in the literature and policies that would affect birth and migration rates. Key variables were selected to describe these trends and quantified by extrapolating past trends described in the literature. Eventually, combinations of hypothetical trends were bundled into five coherent and contrasting scenarios. We did not consider technological change that would result in increased potential yield due to breeding. Although the 15-year time span corresponds to the 'near term' where additional uncertainty due to climate change is assumed to be negligible (Pachauri and Mayer, 2015), climate change is considered an important threat to agriculture in the region (Traore et al., 2017). Hence, to inform decision making towards timely adaptation, we included climate change effects in the sensitivity analysis (Section 2.6).

\subsection{Simulation framework}

A model framework was built to simulate three major farm components (household, cropland and cattle herd) and their interactions (Fig. 1) for each of the 99 farms of the Nampossela village. The model was run for both a baseline situation (2013) and a near-term future situation 15 years later (2027). The baseline and the future situation were each simulated with the same series of 29 historical seasons (1965-1993), which is the only complete weather dataset for which corresponding water-limited potential cotton yields were observed (see Section 2.4.2). For the baseline and the future situation, food self-sufficiency and income per capita were computed for each farm, averaged across the seasons and for each farm type. Also the year-to-year variability was assessed. Furthermore, the percentage of farms above the poverty line and food self-sufficient was computed for both the baseline and the future situation. Hence, the scenario analysis was not based on a continuous temporal change, but on a comparison of separately modelled baseline and future situations, which is common practice (Miguel Ayala et al., 2016; Rajib et al., 2016). The model was built with the $\mathrm{R}$ programming language. Main model input comprised farm characteristics (farm type, area of the different crops, household size, number of tools and animals) and crop/livestock performances (grain, fodder and milk yield) (Fig. 1). Further input to the model comprised net fertility and migration rates and farm and socio-economic conditions derived from the scenarios. More details on parameters, input, output variables and calculations are available in supplementary material as background and resource for readers who are interested to repeat this exercise. In what follows we explain each model component and indicator separately. 


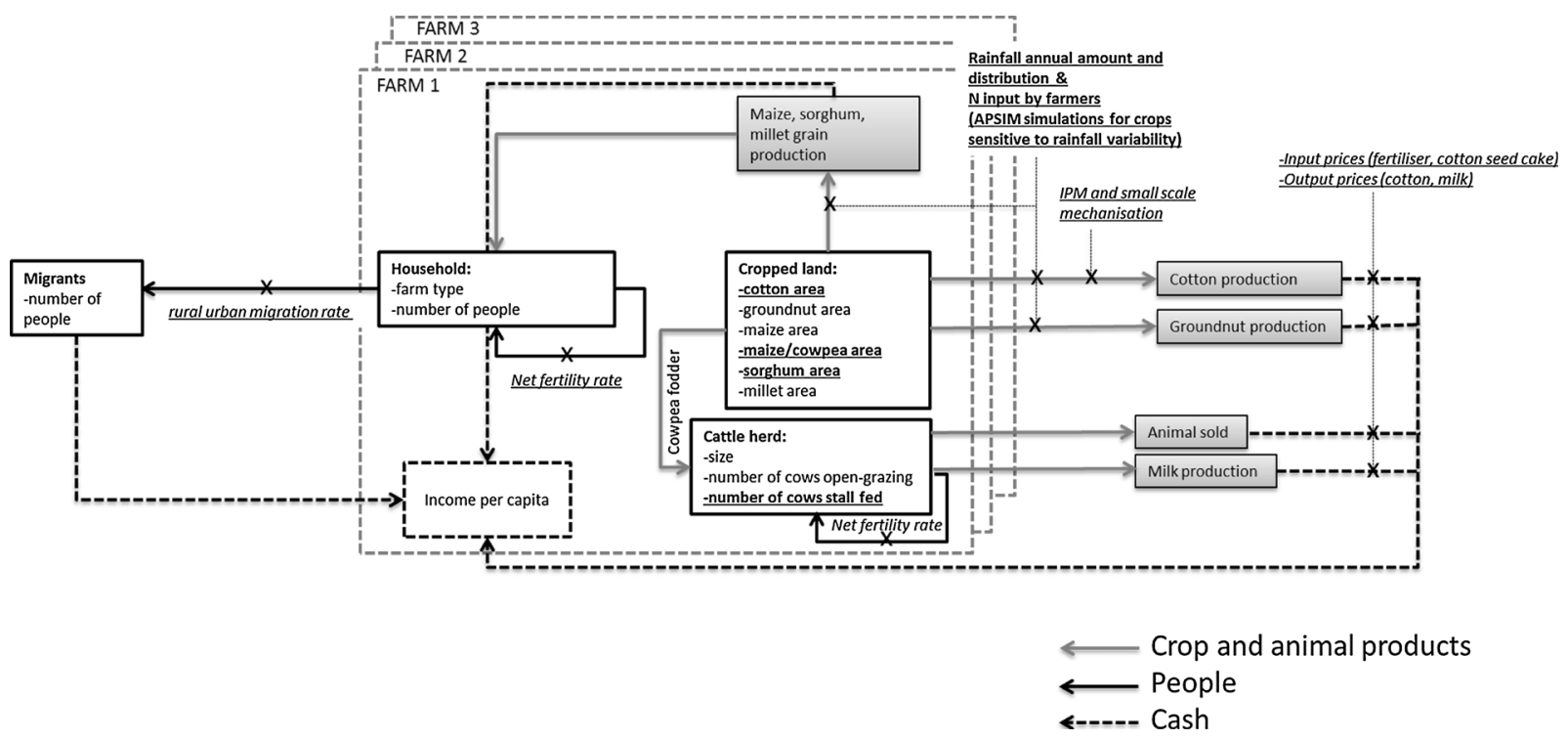

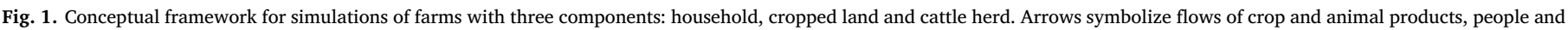

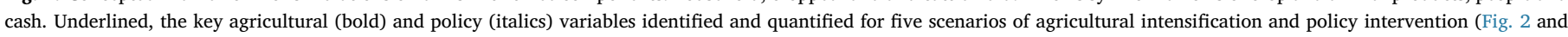
Table 1 give a detailed description of the scenarios). Only three farms are depicted but in reality 99 farms are simulated.

\subsubsection{Household component}

Number of people in each household (Fig. 1) in 2013 (HH_size ${ }_{2013}$ ) was obtained from the village survey data. For each farm, household size in 2027 ( HH_size $_{2027}$ ) was calculated as follow:

(1) HH size $2027=$ HH size $_{2013}[1+(\text { fertilityrate }- \text { migrationrate })]^{2027-2013}$

where fertility_rate is the net (birth-death) fertility rate and migration_rate is the rural to urban migration rate. Fertility rates were specific for each scenario, while migration rates were specific for each scenario and farm type. For each of the four farm types, past average annual growth rate of the household size was calculated using 1994 and 2010 SEP data. Rural-urban migration rate over the 1994-2010 period was estimated as the difference between the observed annual growth rate of household size and the Malian average net fertility (birth-death) rate (3.4\%) (World Bank, http://data.worldbank.org/indicator/SP. DYN.CBRT.IN, last accessed 30/09/2016).

Traditionally, the eldest son inherits the land and becomes the head of the household (comprising the younger brothers), which prevents land subdivision (Jonckers and Colleyn, 1974) except if brothers disagree. The SEP data showed that only one out of 30 households was subdivided during the whole 1994-2010 period (Falconnier et al., 2015). In line with this finding, a comprehensive survey carried out in 2006 showed that $71 \%$ of the 146 farms of another village in the Koutiala district originated from a traditional inheritance process without land holding subdivision and only $29 \%$ originated from a household subdivision, with $86 \%$ of these subdivisions having occurred before 1996 (Poccard-Chapuis et al., 2007). Hence, as population increase results in a decrease in land per capita rather than a decrease in farm size, landholding subdivision was not considered for the simulations. As there is no arable land available for expansion (Falconnier et al., 2015), total cropped land per household (Fig. 1) was kept constant over the 15 years of the simulation.

\subsubsection{Cropped land component}

Information on cropland allocation and area (Fig. 1) in the baseline was obtained from the village survey data. To estimate crop yields with farmer practice as a function of variable rainfall and assess year-to-year variability, we used an empirical approach based on experimental results from the region. Correlations between annual rainfall and yield of cotton, maize, sorghum, millet and groundnut were analysed using published studies reporting measured yield with farmer practices in onstation and on-farm trials in the "old cotton basin". Additionally, cotton yield measured by CMDT in the SEP dataset were analysed. For the crops for which our literature study indicated a significant effect of rainfall on the yield with farmer practice, this yield was simulated using the APSIM model (Keating et al., 2003) and used as an input to the cropland component (Fig. 1). APSIM was calibrated for a typical Lixisol (FAO, 2006), the cultivars used by farmers in the "old cotton basin" (Traore, 2014; Akinseye, personnal communication; Nenkam, personnal communication) and run with $\mathrm{N}$ application rates used by farmers (derived from SEP data). The yields were simulated using the 1965-1993 weather records from N'Tarla station (Traore et al., 2013). For crops without a significant effect of rainfall on yield, the average measured yield in farmer conditions was used and kept constant for all seasons.

With respect to water-limited potential yields (van Ittersum et al., 2013), cotton yields measured from 1965 to 1993 in the N'Tarla experimental station in plots receiving $90 \mathrm{~kg} \mathrm{~N} \mathrm{ha}^{-1}$ mineral fertilizer and $12.8 \mathrm{t}$ dry matter manure ha ${ }^{-1}$ were used (Ripoche et al., 2015). For maize, sorghum and millet, yields were simulated with APSIM using the same settings as above and increasing amount of nitrogen. A nitrogen input of $200 \mathrm{~kg} \mathrm{~N} \mathrm{ha}^{-1}$, spread over two applications, was found to release $\mathrm{N}$ constraints in all years of the simulation and was therefore used for the determination of the water-limited potential yield. Finally, $85 \%$ of the water-limited potential yield and the required $\mathrm{N}$ input were determined, corresponding to the exploitable yield gap (van Ittersum et al., 2013).

\subsubsection{Cattle herd component}

A $10 \%$ net fertility rate for cattle (Fig. 1) was assumed (Ba et al., 2011). Annual animal off-take was assumed to be equal to this net fertility rate to ensure a stable cattle herd size (Ba et al., 2011). Current cattle herd size for each household was obtained from the village survey data. The proportion of lactating cows in the cattle herd was assumed to be 22 and $34 \%$ for cattle herds below and above 23 animals respectively (Ba et al., 2011). Year-round milk production of cows with opengrazing (current farmer practice) and stall feeding ( $2.5 \mathrm{~kg}$ cowpea hay cow $^{-1}$ day $^{-1}$ and $2 \mathrm{~kg}$ cotton seed cake cow ${ }^{-1}$ day $^{-1}$ during the dry hot period of 90 days) was obtained from De Ridder et al. (2015). 


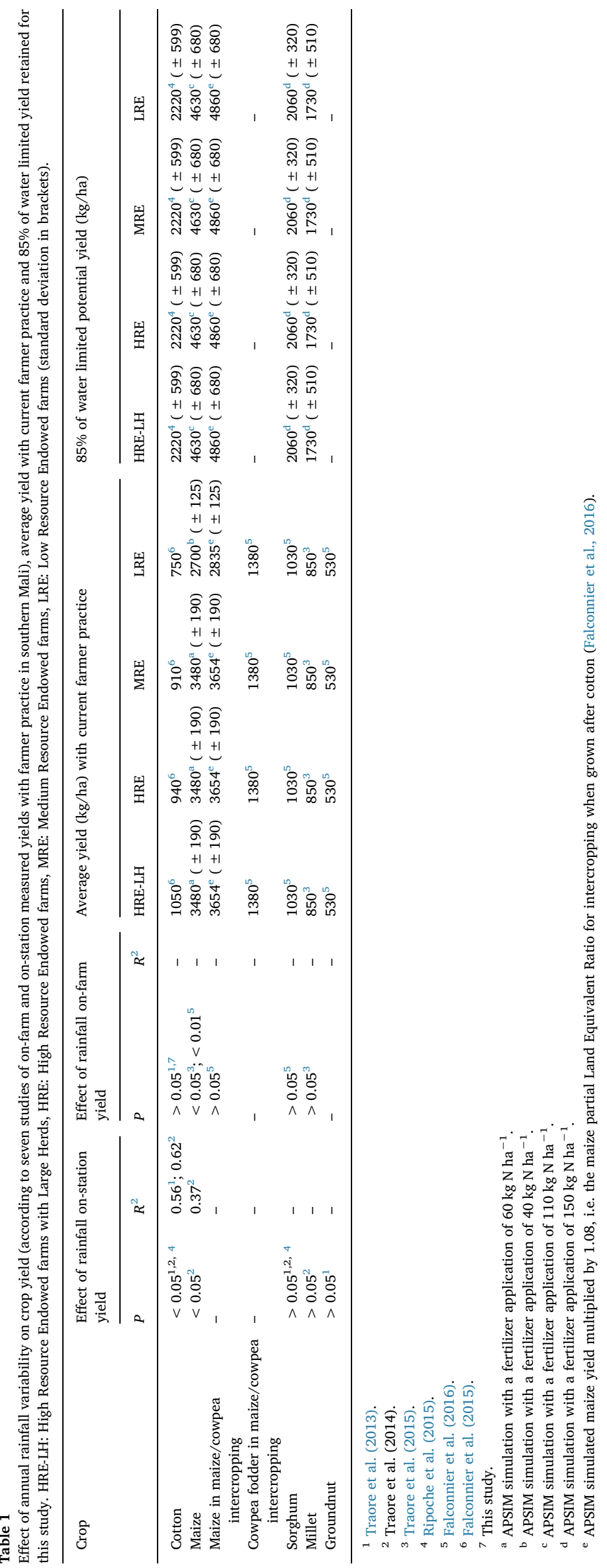




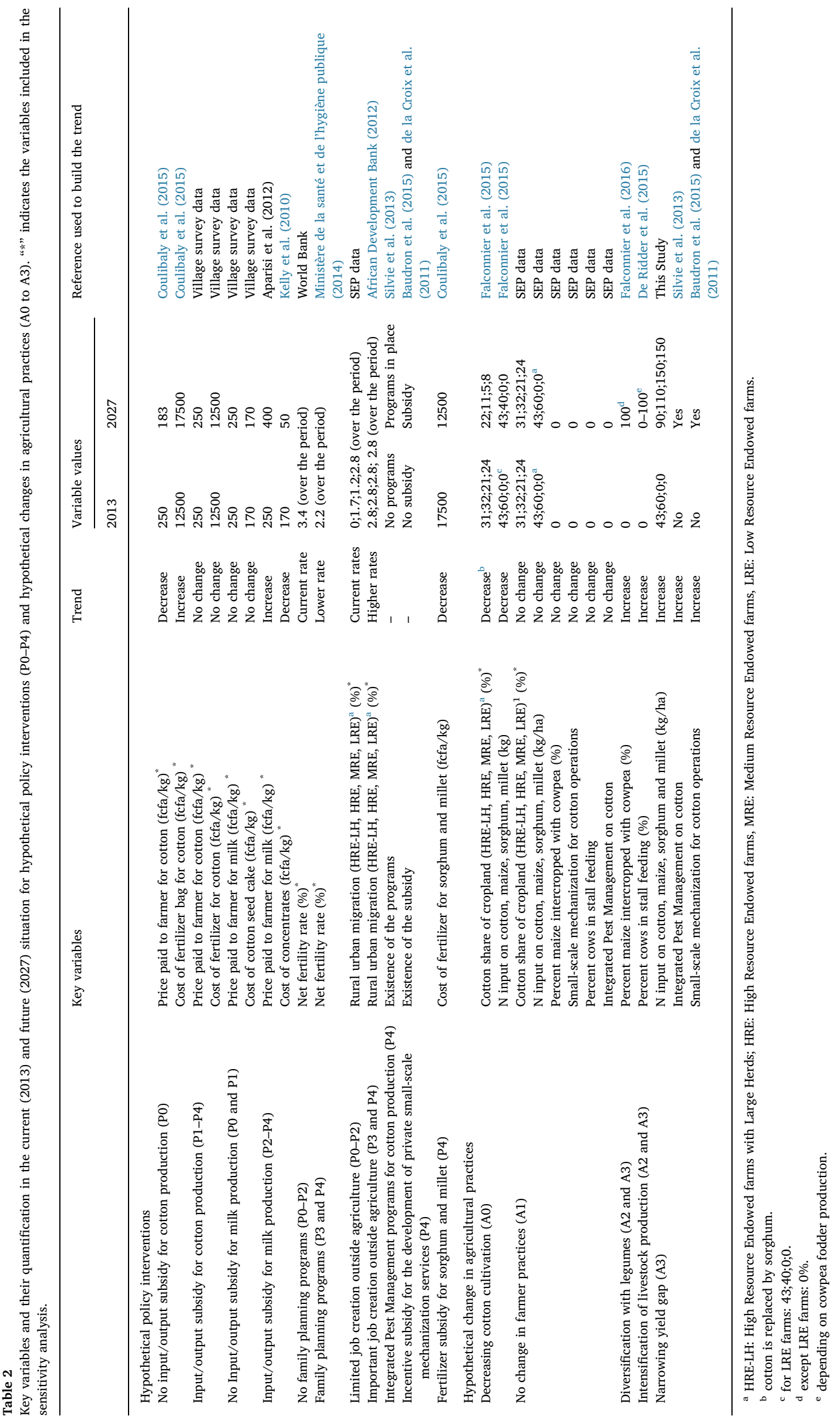




\subsection{Food self-sufficiency and income per capita}

Income per capita (Fig. 1) was calculated as an aggregate of (i) farm income, i.e. monetary gross margins from cotton, groundnut, cereals, milk, live-animal sales, and (ii) non-farm income, i.e. remittances sent by migrants and self-employment (sale on the local rural market of local natural products like wood and charcoal, manufactured goods like baskets and jewellery and services like hair-dressing and repairs of farm equipment). Depreciation of animal drawn equipment (plough, weeder, sowing machines, carts and oxen) was deducted from the income. Transfers related to the remuneration of land (renting), labour (working on anothers' farm) and capital (interest paid for borrowing money), corresponding to $0,2 \%$ and $0.1 \%$ of average income respectively (Samake et al., 2008), were considered negligible.

For cereal gross margin, both self-consumption and surpluses were valued at the market price. Income was expressed in 2011 US dollar Purchasing Power Parity (\$PPP), to allow comparison with the international 1.9 \$PPP/day/person poverty line (Jolliffe and Prydz, 2016; Ravallion et al., 2009). The Average Conversion rate between the Malian currency (FCFA) and \$PPP was obtained from the World Bank estimates (http://databank.worldbank.org/data/reports.aspx?Id = edef810f\&Report_Name $=$ ICP_2011_V3, last accessed 18/10/2017). Input and output prices (Fig. 1) at the start of the simulation (2013) were obtained from a market survey carried out in 2013 in Nampossela. For the end of the simulation period (2027), input and output prices for milk, cotton and cereals depended on the scenarios, while other prices were kept constant.

Food self-sufficiency was calculated as the percent fulfilment of household calorific need by on-farm production of calories. An average calorific need of $2406 \mathrm{kcal} /$ person/day was considered (average across all SEP households using age-sex specific daily needs, following Britten et al., 2006). The calorie supply was computed based on household cereal production, considering an average supply of $3500 \mathrm{kcal} \mathrm{kg}^{-1}$ maize, sorghum and millet grain (FAO: http://www.fao.org/docrep/ t0818e/T0818E0b.htm, last accessed 02/10/2015).

\subsection{Sensitivity analysis}

Variation (from $-50 \%$ to $50 \%$ ) was applied to the default trend in the key variables describing the scenarios. For example, the default trend in cotton price was a $27 \%$ decrease (see Table 2), so that $-50 \%$ variation and $+50 \%$ variation in this default trend corresponded to a $14 \%$ and $41 \%$ decrease in cotton price respectively. Trends in variables were changed one at a time, while keeping others constant (i.e. at their "no change" or "current rate" value, see Table 2).

To factor in the potential (longer-term) effects of climate change, the effect of a decrease in maize, sorghum and millet yield due to an increase in temperature was assessed. We evaluated the future situation (2027) for the different scenarios using APSIM simulated yields for a hypothetical 2040-2069 period. Daily rainfall and temperature data were obtained from five contrasting Global Circulation Models (GCM) and the high-emission $8.5 \mathrm{Wm}^{-2}$ radiative forcing scenario (Traore et al., 2017). APSIM yields were averaged across the five GCMs. The effect of these variations on the key output of the model framework (i.e. percent farms food self-sufficient and non-poor in 2027) was assessed.

\section{Results}

In what follows, we start by giving the results of the literature and data analysis that formed the basis of the hypothetical trends. Then hypothetical trends and scenarios are explained and finally the results of the simulations and sensitivity analysis are presented.

\subsection{Past observed population growth and migration rate}

In the 1994-2010 period, the average observed annual growth rate of household size was $3.4( \pm 0.13), 1.7( \pm 0.78), 2.2( \pm 0.6)$ and $0.6 \%$ ( \pm 1.74 ) for HRE-LH, HRE, MRE and LRE farms respectively. Based on the average net fertility rate of $3.4 \%$ for Mali, estimated rural to urban migration rates were $0,1.7,1.2$ and $2.8 \%$ for HRE-LH, HRE, MRE and LRE farms respectively.

\subsection{Crop yields}

Maize cultivated with farmer practice was sensitive to seasonal rainfall amount in on-station experiments and in on-farm trials (Falconnier et al., 2016; Traore et al., 2013, 2015). Therefore maize yield under current farmer practice was simulated with APSIM and varied with seasonal rainfall conditions and farm type (Table 1). For the diversification trends, maize yield and cowpea fodder production obtained in maize/cowpea intercropping experiments on-farm were considered (Table 1).

On-station experiments showed the sensitivity of cotton yields to seasonal rainfall (Traore et al., 2013). However, cotton yields less in farmers' fields than on station and tends not to be impacted by seasonal rainfall because of pests and weeds (Traore et al., 2013). Analysis of measured yields in the SEP database showed that farmers' cotton yields were not significantly impacted by total rainfall and rainfall distribution, but by manure input $(P=0.02)$ and oxen per worker (which indicates the ability to weed in a timely fashion) $(P<0.001)$, factors that varied per farm type. Therefore, for the current farmer practice the average cotton yield was considered per farm type and kept constant for all the rainfall seasons (Table 1). For sorghum, millet and groundnut no significant correlations were found between yield and seasonal rainfall in on-station and on-farm experiments with farmer practice (Falconnier et al., 2016; Traore et al., 2013, 2015). Also, no effect of farm type was diagnosed. Therefore, for the scenarios with current farmer practices, average yields obtained in on-farm trials with farmer practice were considered (Table 1) and kept constant for all the rainfall seasons.

The simulated water-limited potential yield for the cereals were obtained with increased nitrogen inputs and resulted in an increased sensitivity to rainfall (illustrated by the larger standard deviation in Table 1).

\subsection{Policy interventions}

Five policy interventions were conceived, from negative (P0) to 'business as usual' (P1) to incrementally progressive (P2-P4).

\subsubsection{Input and output prices}

Policy interventions related to agricultural input and output prices were considered in three domains. Firstly, a continued decline in cotton prices and a structural removal of fertilizer subsidies is not unlikely in the near future (Coulibaly et al., 2015). Based on these projections, a pessimistic hypothetical policy trend (P0) included a steady decline in the cotton price and a steady increase in mineral fertilizer prices (Table 2). In more optimistic projections (P1-P4), the cotton price and fertilizer subsidy would be maintained at the 2011-2015 level (Falconnier et al., 2015). Secondly, in 2008 the high price of milk powder on the world market decreased milk powder importations, obliging dairy industries in Bamako to use more local milk (Aparisi et al., 2012). In combination with the increased popularity of products from local milk (Corniaux et al., 2012), this led to a $10 \mathrm{Fcfa} / \mathrm{L} / \mathrm{year}$ increase in the price paid to farmers by dairies from 2005 to 2010 . Together with the official food sovereignty objective of the LOA and the lobbying by the West African farmer organization "Réseau des Organisations Paysannes et Professionnelles Agricoles" to raise the Common External Tariff of agricultural commodities in the Economic Community of West African States (Laroche Dupraz and Postolle, 2013), this formed the basis of a progressive policy intervention with tariffs on milk powder (P2-P4). Thirdly, the market for cotton by-products is poorly understood (Kelly et al., 2010). However, we hypothesised that in the 
favourable policy trends (P2-P4), the cotton seed cake price would decrease to its lowest level observed in 2003 (Kelly et al., 2010). In the other trends, the current low price for milk and high price for cotton seed cake would be continued (P0 and P1).

\subsubsection{Socio-economic development}

Policy interventions related to socio-economic development were considered in two domains. Firstly the Malian government committed to family planning with a plan aiming at "increasing the rate of contraceptive use in Mali, moving from $9.9 \%$ in 2012 to at least $15 \%$ by 2018 , through the reduction of unmet need for family planning and by targeting teens and young adults (aged 15-24)" (Ministère de la santé et de l'hygiène publique, 2014). Family planning can decrease net fertility rates (Bongaarts, 2011) but the effect of such a program has not been quantified for Mali. Hence, we hypothesised that family planning would lead to a $35 \%$ decrease in fertility rates down to the Côte d'Ivoire level of $2.2 \%$ (P3 and P4, Table 2). Furthermore creation of jobs outside of agriculture and educational programs to empower rural people can favour rural to urban migration (de Brauw et al., 2014; Fox and Sohnesen, 2012). The Malian government promoted youth employment with the establishment of several programs aimed at training young people and young entrepreneurs in promising sectors (e.g. industry, mining, information and communication technologies) (African Development Bank, 2012). We assumed that the continuation and strengthening of such policy intervention would lead to rural to urban migration rates of $2.8 \%$ for all farm types during the 2013-2027 period (i.e. the highest observed rate in the 1994-2010 period) (P3 and P4, Table 2).

\subsubsection{Narrowing yield gap}

The comparison of water-limited potential yield and actual yield indicated a large yield gap for cotton despite the use of mineral and organic fertilizer by farmers (with $43 \mathrm{~kg} \mathrm{~N} \mathrm{ha}^{1}$ and $4.9 \mathrm{tha}^{1}$ dry matter manure on average, cotton with farmer practice yielded only $47 \%$ of the water-limited potential yield), pointing to important pest and weed pressure. In Mali, various interventions have promoted Integrated Pest Management, and the cotton area with Integrated Pest Management rose from 104 ha in 1994-92500 ha in 2010 (Silvie et al., 2013), representing still only $33 \%$ of the total cotton area. To narrow the cotton yield gap, we conceived a policy intervention (P4) geared towards (i) relieving pest and weed constraints, through further Integrated Pest Management programs, i.e. training of farmers to improve spray scheduling (Hillocks, 2014) and (ii) timely land preparation, sowing and weeding of cotton through subsidies for the development of private small-scale mechanization services to alleviate the shortage in land cultivation equipment (Baudron et al., 2015; de la Croix et al., 2011) (Table 2). In addition to that, P4 included the extension of the fertilizer subsidy to sorghum and millet (currently only on cotton and maize) to incentivize farmers to apply more nitrogen on cereals, allowing to reach $85 \%$ of water-limited potential yield for maize, sorghum and millet (Table 2). This policy would be similar to the expansion of the "Initiative Riz" undertaken by the Malian government in 2009 to extend fertilizer subsidies to sorghum and millet (Kelly et al., 2011).

\subsection{Agricultural intensification}

Falconnier et al. (2015) showed that in the unfavourable cotton context of the past decades, the cotton area of HRE-LH, HRE, MRE and LRE farmers decreased by $30,66,75$ and $66 \%$ and was replaced by sorghum. This cotton area shrinkage, alongside a decrease of mineral fertilizer use down to the level of LRE farms was assumed for the less optimistic agricultural change (A0) (Table 2). In the second hypothetical change (A1), no change in farmer practices was assumed (Table 2). A third trend of agricultural intensification (A2) assumed the adoption of maize/cowpea intercropping (i.e. diversification with legumes) and stall feeding of lactating cows (i.e. intensification of livestock production) using the cowpea fodder produced on-farm (Table 2). This change was based on findings of a series of co-learning cycles involving farmers of the four farm types (HRE-LH, HRE, MRE and LRE) during three years of research in the study area. The co-learning cycles were composed of (i) on-farm testing of intercropping and stall-feeding options by about hundred farmers in nine villages of the Koutiala region, (ii) appraisal of options by farmers, and (iii) farm system re-designs and ex-ante analysis assessed by farmers (Falconnier et al., 2016, 2017). The co-learning process indicated that maize-cowpea intercropping is a low-risk, profitable option, which can be combined with stall feeding of lactating cows for increased milk production without compromising food self-sufficiency of the household.

A final trend towards agricultural intensification (A3) entailed an increase in the use of mineral fertilizer on maize, sorghum and millet up to the level required to reach $85 \%$ of potential yields, and adoption by cotton producers of small-scale mechanization and Integrated Pest Management (Table 2).

Fig. 1 gives a comprehensive picture of how the agricultural and policy variables constituting the trends listed in Table 2 impacted the components of the model framework.

\subsection{Scenarios}

Five scenarios resulted from the logical combinations of the trends in policy and agricultural intensification (Fig. 2). In the "Marginalisation" (SO) scenario, enabling policies disappear and cotton cultivation and fertilizer use decrease. In the "Business as usual" (S1) scenario, current policies supporting cotton are maintained and farmer practices do not change. The other scenarios rely on incremental policy interventions triggering a change in farmer practices toward agricultural intensification. In the "Dairy development" (S2) scenario, policy interventions extend to the milk sector, triggering cropping diversification with legumes and intensification of livestock production. The "Socio-economic development" (S3) scenario builds on S2, with additional family planning to reduce human fertility rates and job creation outside agriculture to favour rural to urban migration. The "Narrowing yield gap" (S4) scenario is the most optimistic scenario with all the previous policy interventions put in place, and additional interventions to narrow the yield gaps.

\subsection{Change in food self-sufficiency and income per capita for different scenarios}

All farm types were food self-sufficient on average in 2013, with some variation due to the sensitivity of maize to rainfall (Fig. 3). In S0, average food self-sufficiency decreased for HRE-LH and MRE farms but increased slightly for LRE farms. In S1 and S2, average food self-sufficiency in 2027 decreased compared with the baseline 2013 for all farm types. In S3, food self-sufficiency was maintained at around its 2013 level for all farm types. In S4, food self-sufficiency and its variability increased for all farm types.

In 2013, only HRE-LH farms were above the poverty line in all seasons (Fig. 3). In S0 and S1, income per capita decreased (all farm types except LRE farms) and was below the poverty line, regardless of rainfall. In S2, income per capita was maintained at around its 2013 level, except for LRE (increase) and HRE-LH (decrease). S3 allowed all farm types to increase their income compared with 2013 and move above the poverty line in all seasons. In S4, all farm types increased their income per capita compared with the baseline (2013) and stayed non-poor. The variability in income per capita also increased in S4.

In the baseline year (2013), 26\% ( $\pm 0.5 \%$ depending on the rainfall season considered) of farms of the village were non-poor and food selfsufficient (Fig. 4). In S0, S1 and S2 this percentage fell to $6 \%( \pm 0.1 \%$ ), $13 \%( \pm 0.3 \%)$ and $27 \%( \pm 0.2 \%)$ respectively. With $\mathrm{S} 3,77 \%$ ( $\pm 0.2 \%$ ) of the farms were non-poor and food self-sufficient, and this percentage further rose to $94 \%( \pm 1.4 \%)$ in S4. 


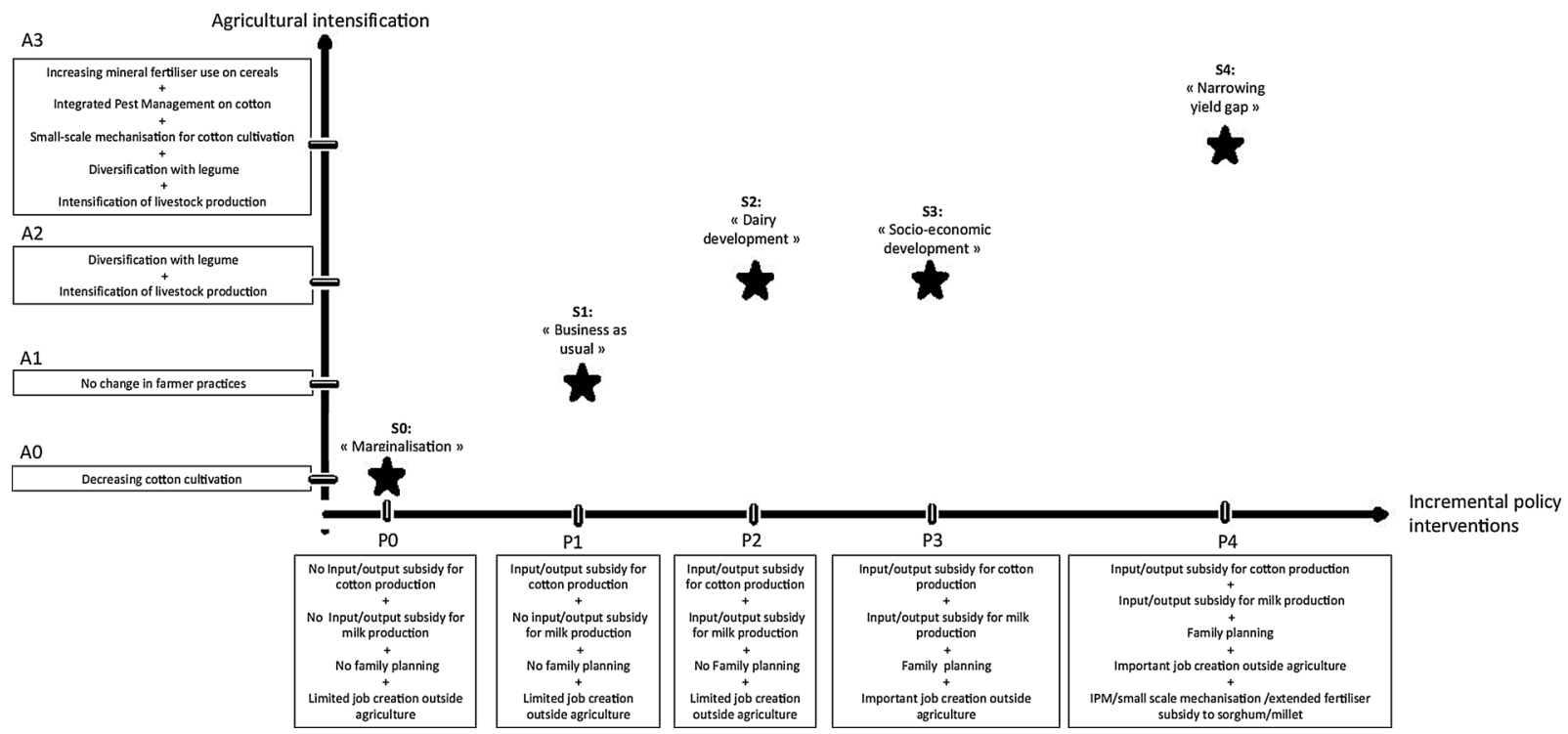

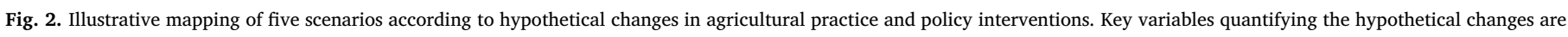
described in Table 1.
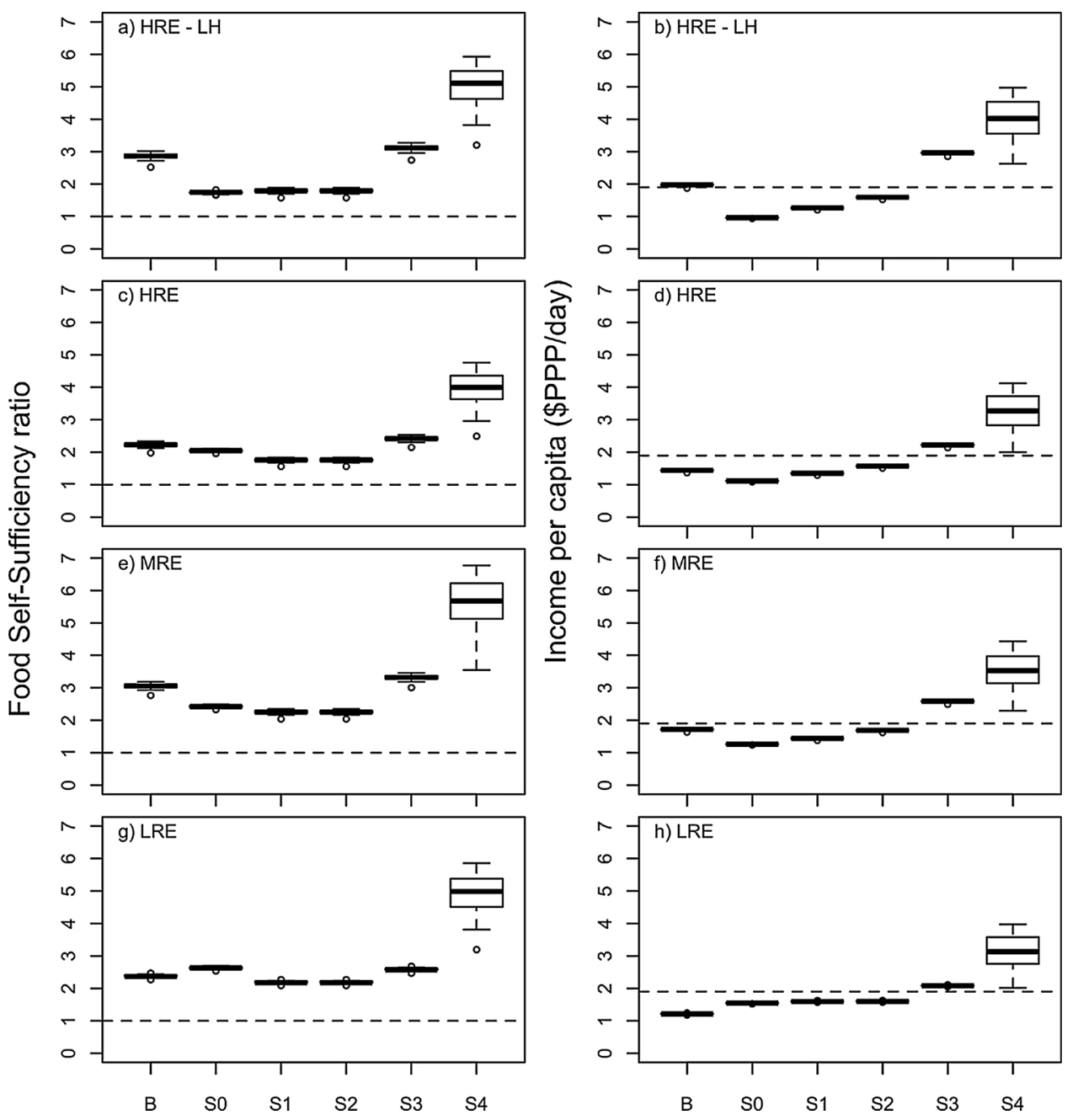

Fig. 3. Boxplots showing food self-sufficiency and farm income per capita averaged for High Resource Endowed with Large Herds (a,b), High Resource Endowed (c,d), Medium Resource Endowed (e,f), and Low Resource Endowed (g,h) farms in 2013 for the baseline (B) and in 2027 for five scenarios of agricultural intensification and policy intervention (S0-S4). The horizontal dotted line is the food selfsufficiency threshold (a,c,e,g) and the poverty line threshold of 1.25 \$PPP/day (b,d,f,h). A detailed description of the scenarios (SO-S4) can be found in Fig. 2 and Table 1. The horizontal line in the box indicates the median for 29 rainfall seasons. The height of the box represents the interquartile range. The whiskers extend to the most extreme data point which is no more than 1.5 times the interquartile range from the edge of the box.

\subsection{Sensitivity analysis}

Variations in the default trends in rural-urban migration, net fertility rate and cotton price led to large changes in the simulated percentage of farms that were food self-sufficient and non-poor in 2027 (Fig. 5). For example, the default decrease in net fertility was $35 \%$ in the policy interventions with family planning (P3 and P4, from $3.4 \%$ to $2.2 \%$, see Table 2 ). For a $+50 \%$ deviation from this default trend (from 

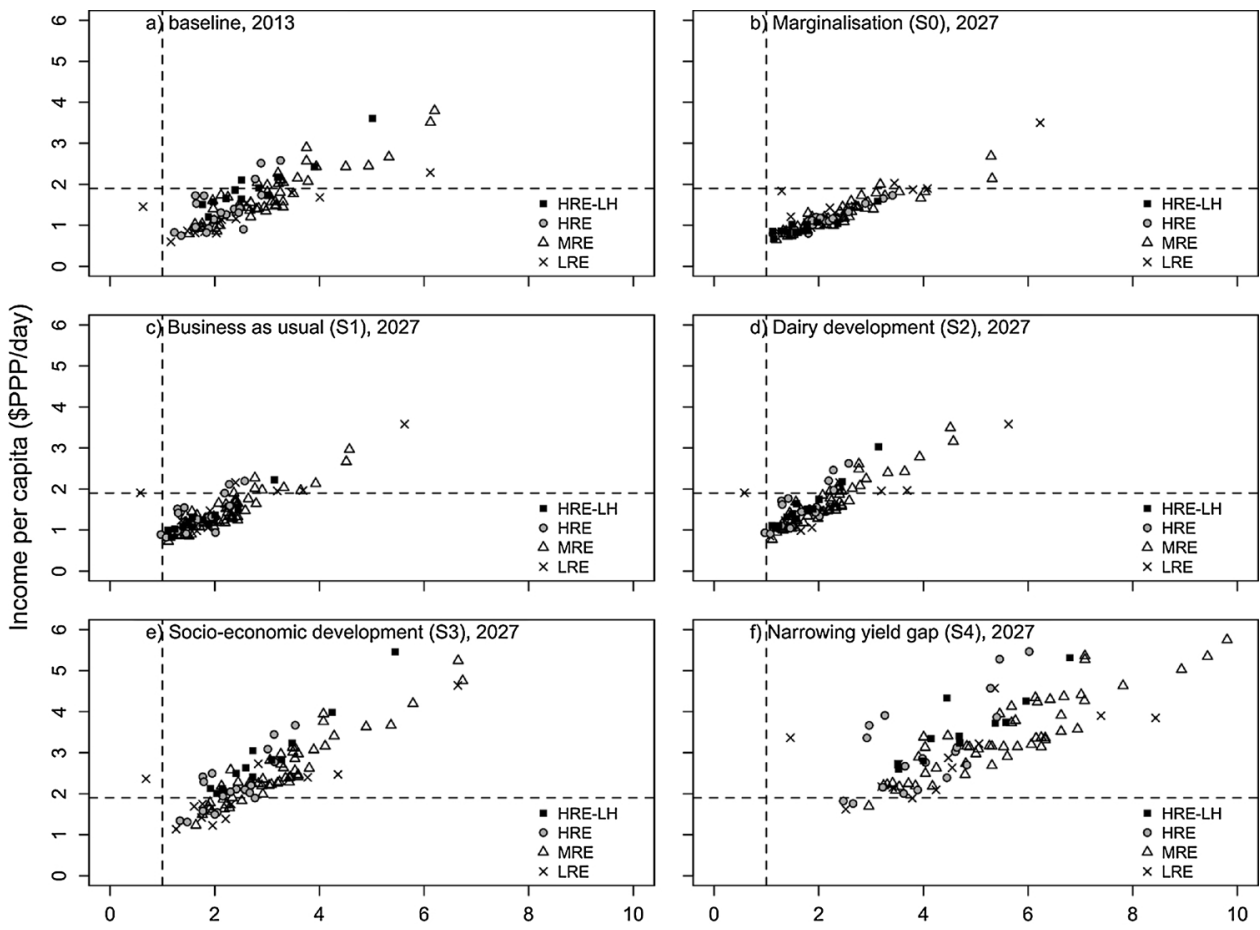

Food Self-Sufficiency

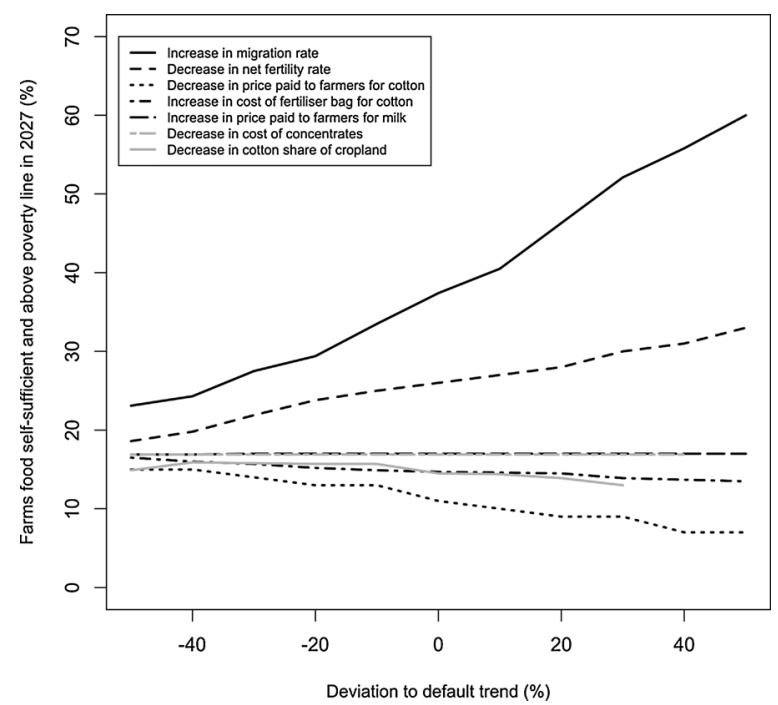

Fig. 5. Percent farms food self-sufficient and above poverty line in 2027 for $\pm 50 \%$ variation in the default trend in the key variables constituting five scenarios of agricultural intensification and policy interventions.

$3.4 \%$ to $1.6 \%$ ) and all other variables kept to their "no change" value (see Table 2), the simulated percentage of farms food self-sufficient and non-poor in 2027 increased from $26 \%$ to $33 \%$ (i.e. a $7 \%$ percentage point increase). Variation to the default trend of the other variables impacted only marginally the final output of the model framework (Fig. 5).

A decrease in cereal yield due to temperature increase would lead to a $2 \%$ percentage point decrease in the percentage of farms food selfsufficient and non-poor in 2027 in S0, and 8\% in S1, S2 and S3 scenarios (Table S3).
Fig. 4. Food self-sufficiency ratio and income per capita of the 99 households of Nampossela village in 2013 (a) and 2027 for different scenarios of agricultural intensification and policy intervention $(b, c$, $\mathrm{d}$, e, f) for an average rainfall year $(734 \mathrm{~mm})$. The horizontal and vertical dotted lines represent the $1.25 \$ \mathrm{PPP} /$ day poverty line and the food self-sufficiency threshold respectively.

\section{Discussion}

\subsection{Change in food self-sufficiency and income differed per farm type}

Differing migration rates between farm types led to different changes in food self-sufficiency and income per capita (Fig. 3). This factor was overriding differences in farm livestock holdings, practices and yields.

Out-migration in search of remunerative activities is a major element of survival strategies in West Africa (Painter et al., 1994). Our estimate of rural to urban migration rates during the 1994-2010 period for farms in the old cotton basin (from 0 to $2.8 \%$ depending on farm type) is in line with the $2 \%$ rate reported by de Brauw et al. (2014) for Mali. In an additional survey carried out in 2012, SEP farmers explained that household members migrated to Malian, African, or European cities (73, 27 and $3 \%$ of the farms respectively). This low percentage of people migrating to Europe from the Koutiala region explains why remittances are fairly low (180 \$PPP per migrant per year) in the Koutiala region, compared with the Diema region for example which is known for having a high emigration to European countries (remittance of 1233 \$PPP per year per migrant) (Losh et al., 2011). Usually, migration is a result of the difference between the expected return to labour in the home and the potential destination area (Harris and Todaro, 1970; Jayne et al., 2014). Logically, the farms with the lowest labour productivity, i.e. the HRE and LRE farms (Falconnier et al., 2015), experienced the highest migration rate in the 1994-2010 period (see Section 3.1). In the "Business as usual" (S1) scenario, higher out-migration relieved some of the pressure on land and provided more remittances for HRE and LRE farms who therefore suffered from a smaller decrease in food self-sufficiency and income per capita compared with HRE-LH and MRE farms (Fig. 3). Similarly in the "Dairy development" (S2) scenario, HRE farms experienced an increase in income per capita while it decreased for HRE-LH farms although the latter farm type had more cattle and therefore more potential to benefit from improvements in the milk sector. In HRE-LH farms without out- 
migration, population growth outpaced the benefits associated with diversification with legume and intensification of livestock production. It was only when out-migration was stimulated by job creation in the cities and rural towns (S3), that the benefits of dairy development could be seen for HRE-LH farms (Fig. 3a and b). Interestingly, though they owned less livestock than HRE and HRE-LH farms, MRE farms also benefited from dairy development because they were able to sell surplus cowpea fodder (Fig. 3f). LRE farms had low income per capita in the baseline, due to their small cotton area and yield. Population growth had very little impact on these small farms given their high rate of out-migration. They owned a very small number of cattle (Falconnier et al., 2015) and therefore didn't benefit from interventions in the milk sector. As a consequence, they remained "hanging in" with low income per capita in the scenarios S0 to S2 (Fig. 3h).

Out-migration could have a detrimental effect on yield due to labour loss. However, in the S3 and S4 scenarios, where the increase in population density is counteracted by family planning and out-migration measures, the latter just offset rather than outpaced population growth. As a result, the number of people in the household in 2027 was similar to the number of people in the baseline year (see Fig. S1) so that no labour shortage had to be expected. Falconnier et al. (2017) showed that with actual household size and cropland area, there is no human labour shortage for cropping activities; the shortage is rather in the availability of oxen. If higher out-migration rates had to be considered in other studies, leading to lower number of people compared with the baseline, an effect of labour loss on yield could be introduced in the modelling framework. The ratio "available labour/required labour" (for crop operations) could be applied to decrease crop yields in the case of insufficient labour.

\subsection{Pathways out of poverty?}

The marginalisation scenario (S0) strongly resembled the experience of farmers during the period of instability in the cotton sector (2004-2010) (Nubukpo, 2011). The partial replacement of cotton by sorghum, allowed LRE farms to improve their food self-sufficiency status (Fig. 3c and g), but also increased poverty rates in the case of HRE farms (Fig. 4b). The sensitivity analysis indicated that the increase in poverty rates could be amplified if cotton prices paid to farmers would decrease more strongly. Overall, this stresses the crucial role of a well-functioning cotton sector for poverty alleviation in the region (Djouara et al., 2005).

Dairy development is usually considered unlikely in land-constrained environments, due to the strong competition of forage production with existing cash or food crops (De Ridder et al., 2015; Herrero et al., 2014). However, in the "Dairy development" (S2) scenario, the decrease in food self-sufficiency was due to demographic growth, and not to trade-offs between food and fodder production. This was achieved by intercropping cowpea with maize after cotton in the rotation, a niche that guarantees no penalty to maize production (Falconnier et al., 2016). To achieve this type of scenario in reality, an integrative "innovation system" is required where farmers have more political control over the agricultural sector and the policies affecting it (Röling, 2009). Diversification with legume and intensification of livestock production need to be supported by a more favourable milk input/output price ratio, the envisaged outcome of lobbying activities against tariffs for milk imports (Laroche Dupraz and Postolle, 2013). Farmers' policy influence in southern Mali is still weak compared with farmers in France, The Netherlands or the United States for example (Röling, 2009). However, the example of the Agricultural Producers' Organisations of West Africa (ROPPA) regrouping 50 millions farmers across West Africa and defending the right for African states to develop agricultural policies against dumping from Europe (Laroche Dupraz and Postolle, 2013) provides hope that this is not unrealistic.

When dairy development is coupled with socio-economic development and price interventions in the milk sector (S3), a significant proportion of the village is lifted out of poverty (Fig. 4e). Our study adds to the body of literature showing that out-migration can relieve land pressure and improve livelihoods by pulling rural labour out of agriculture and providing remittances (Beegle et al., 2010; de Brauw et al., 2014). The sensitivity analysis indicated that the livelihood improvement could be strengthened with higher out-migration rates. Rural to urban migration however encompasses a diversity of realities and can be the expression of either "unskilled rural labour being pushed out of agriculture" or educated people "pulled into productive non-farm jobs" (Jayne et al., 2014). There is evidence across sub-Saharan Africa that rural to urban migration can be a "pull" into productive non-farm jobs: in Ethiopia, successful industrial development led to the substitution of shoes imported from China by locally manufactured leather shoes (Sonobe et al., 2009). With a more favourable industrial environment, Mali could develop its textile industry and become a competitive exporter (Cockburn et al., 1999). More generally, Fine et al. (2012) estimated that 122 million young people will get into the labour market in Africa between 2010 and 2020. In an optimistic scenario, they projected that Africa could create only 70 million wage-paying jobs, mainly in manufacturing, government and service sectors. The size of the labour force therefore appears to be growing faster than economies can create job opportunities (Fox and Sohnesen, 2012) and agriculture will still have an important role to play in poverty reduction.

Family planning exerted the same influence as out-migration and allowed improving farmers' livelihood. In Mali, demographic surveys indicated that $28 \%$ of the women expressed an unmet demand for contraception (Population Council and ICF International, 2015), showing the scope for a change in reproductive behaviour and the need for stronger political commitment to family planning. Husband's disapproval may however discourage women from taking control of their fertility (Barnett et al., 1999) and a broader change in social and gender norms would therefore be needed. Raising the female education level would allow increasing women potential earnings and bargaining power in the household, which can contribute to reduce fertility rates (Canning et al., 2015). In Kenya, a 30\% reduction in net fertility rate (from 3.7 to $2.8 \%$ ) was achieved within a 15 years timespan (1980-1995) (World Bank, http://data.worldbank.org/indicator/SP. DYN.CBRT.IN, last accessed 29/09/2016), indicating that the decrease in net fertility rates considered in our simulation $(-35 \%)$ would be achievable if appropriate measures were taken. A stronger reduction in net fertility rates could further improve poverty reduction (Fig. 5).

When added to the previous interventions and change in practices, narrowing the yield gap allowed a massive increase in food self-sufficiency (Fig. 3) and lifted almost the totality of the village out of poverty (Fig. 4f). However, at the same time, it increased the variability of food self-sufficiency and income, because of increased crop sensitivity to rainfall when nutrient limitation is alleviated (Affholder, 1995; Ripoche et al., 2015). In 'bad' seasons, small yields would push some HRE farms close to the poverty line (Fig. 4h). This risk of unfavourable cost:benefit ratios is common in the context of sub-Saharan Africa (Bielders and Gérard, 2015; Ronner et al., 2016) and could impede the adoption of higher fertilizer application rates. As yields have been stagnant in the past 20 years (Falconnier et al., 2015), this scenario of narrowing the yield gap in only 15 years is very ambitious. Moreover, it is questionable from a sustainability point of view, because extensive subsidy programs put a heavy load on public agricultural investments and potentially remove finances from other areas of agricultural development (Marenya et al., 2012).

Due to increased temperatures, climate change is expected to have adverse effects on crop yields (Sultan et al., 2013). Our analysis showed that this would negatively affect income per capita and significantly reduce the percentage of farms non-poor and self-sufficient, hence highlighting the vulnerability of the smallholder population. Adaptation to climate change is thus a key aspect of policy making that should start today in order to be ready for a warmer future. Effective policy making should support the co-design of adaptation options with all 
stakeholders including farmers and researchers (e.g. adoption of improved/adapted varieties and adjustment of planting times and fertilization) (Guan et al., 2017; Traore et al., 2017). Furthermore, progressive institutional arrangements such as the development of insurance schemes, weather forecasting, and early warning systems will be key to encourage the adoption of these adaptation strategies. Other transformative measures, e.g. building the capacity of farmers to diversify cropping systems, improve market functioning and value chains development should also be a priority (Descheemaeker et al., 2016).

The case study village is representative for other sites with similar agro-ecological and socio-institutional factors (cotton/cereal rotations and variable rainfall, high population pressure, credit for inputs and guaranteed purchase of cotton). The pathways out of poverty identified here therefore hold for the broad "old cotton basin" that accommodates more than a million of rural people. Finally, our analysis indicates that none of the tested policy interventions and agriculture intensification strategies alone can lift an entire heterogeneous farm population out of poverty (Fig. 4). It is rather the strategic combination of different multisectoral interventions that may offer a solution for poverty alleviation. This key finding adds to the increasing recognition that understanding the future of agriculture requires to move from a singular focus on agricultural interventions to a more holistic and multisectoral analysis (Frelat et al., 2016; Thompson and Scoones, 2009).

\section{Conclusion}

Five scenarios combining incremental policy interventions and agricultural intensification were explored for a village of 99 households in the 'old cotton basin' in Southern Mali. For land-constrained areas like the study region, differential rural-urban migration rates appeared to be a key factor in understanding the different responses of the farms types. To guarantee food self-sufficiency and poverty reduction in the case of a variable climate, the creation of wage jobs to allow people to move out of agriculture and family planning to reduce human fertility rates should complement agricultural intensification interventions. Our study showed that, along with changes in farmer practices towards intensification, several incremental policy interventions in different sectors are needed to lift the entire farm population above the poverty line. This calls for a holistic and multisectoral assessment of plausible futures when trying to reduce rural poverty in land constrained Africa.

\section{Acknowledgements}

Funding for this research was provided by the McKnight Foundation $\left(\mathrm{N}^{\circ} 12-112\right.$ and 12-634) through the project 'Pathways to Agro-ecological Intensification of Sorghum and Millet Cropping Systems of Southern Mali'. We thank the Institut d'Economie Rurale (IER) and Cirad for making available the SEP panel dataset and the N'Tarla longterm experiment dataset. We are grateful to the CMDT who made available the Nampossela household survey. We thank Andrée Nenkam and Folorunso Akinseye for making available APSIM calibrations for maize, sorghum and millet. We thank the AgMIP research community for their contributions to the crop modelling activities and the United Kingdom Department for International Development for their support of AgMIP.

\section{Appendix A. Supplementary data}

Supplementary data associated with this article can be found, in the online version, at http://dx.doi.org/10.1016/j.landusepol.2017.10. 044.

\section{References}

Affholder, F., 1995. Effect of organic matter input on the water balance and yield of millet under tropical dryland condition. Field Crops Res. 41, 109-121. http://dx.doi.org/
$10.1016 / 0378-4290(94) 00115-S$.

African Development Bank, 2012. African Economic Outlook 2012. Special Theme: Promoting Youth Employment. OECD Publishing. http://www.oecd-ilibrary.org/fr/ development/african-economic-outlook-2012 aeo-2012-en.

Aparisi, A.M., Diallo, F., Balié, J., 2012. Analyse des incitations et pénalisations pour le lait au Mali. FAO, Rome. http://www.fao.org/3/a-at572f.pdf.

Ba, A., Lesnoff, M., Poccard-Chapuis, R., Moulin, C.-H., 2011. Demographic dynamics and off-take of cattle herds in southern Mali. Trop. Anim. Health Prod. 43, 1101-1109. http://dx.doi.org/10.1007/s11250-011-9808-2.

Barnett, B., Konaté, M., Mhloyi, M., Mutambirwa, J., Francis-Chizororo, M., Taruberekera, N., Ulin, P., Konate, M., 1999. The impact of family planning on women's lives: findings from the women's studies project in Mali and Zimbabwe. Afr. J. Reprod. Health 3, 27. http://dx.doi.org/10.2307/3583226.

Baudron, F., Sims, B., Justice, S., Kahan, D.G., Rose, R., Mkomwa, S., Kaumbutho, P., Sariah, J., Nazare, R., Moges, G., Gérard, B., 2015. Re-examining appropriate mechanization in Eastern and Southern Africa: two-wheel tractors, conservation agriculture, and private sector involvement. Food Secur. 7, 889-904. http://dx.doi.org/ 10.1007/s12571-015-0476-3.

Beegle, K., De Weerdt, J., Dercon, S., 2010. Migration and economic mobility in Tanzania: evidence from a tracking survey. Rev. Econ. Stat. 93, 1010-1033. http://dx.doi.org/ 10.1162/REST a 00105.

Benjaminsen, T.A., Aune, J.B., Sidibé, D., 2010. A critical political ecology of cotton and soil fertility in Mali. Geoforum 41, 647-656. http://dx.doi.org/10.1016/j.geoforum. 2010.03.003.

Bielders, C.L., Gérard, B., 2015. Millet response to microdose fertilization in SouthWestern Niger: effect of antecedent fertility management and environmental factors. Field Crops Res. 171, 165-175. http://dx.doi.org/10.1016/j.fcr.2014.10.008.

Bizikova, L., Pintér, L., Tubiello, N., 2015. Normative scenario approach: a vehicle to connect adaptation planning and development needs in developing countries. Reg. Environ. Change 15, 1433-1446. http://dx.doi.org/10.1007/s10113-014-0705-x.

Bongaarts, J., 2011. Can family planning programs reduce high desired family size in SubSaharan Africa? Int. Perspect. Sexual Reprod. Health 37, 209-216. http://dx.doi.org/ 10.1363/3720911.

Britten, P., Marcoe, K., Yamini, S., Davis, C., 2006. Development of food intake patterns for the MyPyramid Food Guidance System. J. Nutr. Educ. Behav. 38, S78-S92.

Canning, D., Raja, S., Yazbeck, A.S. (Eds.), 2015. Africa's Demographic Transition: Dividend or Disaster? The World Bank. http://dx.doi.org/10.1596/978-1-46480489-2.

Cockburn, J., Siggel, E., Coulibaly, M., Vézina, S., 1999. Measuring competitiveness and its sources: the case of Mali's manufacturing sector. Can. J. Dev. Stud. 20, 491-519. http://dx.doi.org/10.1080/02255189.1999.9669852.

Corniaux, C., Vatin, F., Ancey, V., 2012. Lait en poudre importé versus production locale en Afrique de l'Ouest: vers un nouveau modèle industriel? Cahiers Agric. 21, 18-24. http://dx.doi.org/10.1684/agr.2012.0536.

Coulibaly, J.Y., Sanders, J.H., Preckel, P.V., Baker, T.G., 2015. Will cotton make a comeback in Mali? Agric. Econ. 46, 53-67. http://dx.doi.org/10.1111/agec.12140.

Coulibaly, A., 2003. Country Pasture and Forage Resources Profiles. FAO, Rome. http:// www.fao.org/ag/agp/agpc/doc/counprof/PDF\%20files/Mali-English.pdf.

de Brauw, A., Mueller, V., Lee, H.L., 2014. The role of rural-urban migration in the structural transformation of Sub-Saharan Africa. World Dev. Econ. Transform. Afr. 63, 33-42. http://dx.doi.org/10.1016/j.worlddev.2013.10.013.

de la Croix, K., Marie, J., Ferry, L., Landy, F., 2011. New dynamics of farming mechanization: trade, uses and spatialization in the Ségou region (Mali). Ann. Geogr. Nubukpo 174-192.

De Ridder, N., Sanogo, O.M., Rufino, M.C., van Keulen, H., Giller, K.E., 2015. Milk: the new white gold? Milk production options for smallholder farmers in Southern Mali. Animal 1-9. http://dx.doi.org/10.1017/S1751731115000178.

Descheemaeker, K., Oosting, S.J., Homann-Kee Tui, S., Masikati, P., Falconnier, G.N., Giller, K.E., 2016. Climate change adaptation and mitigation in smallholder croplivestock systems in Sub-Saharan Africa: a call for integrated impact assessments. Reg. Environ. Change 16, 2331-2343. http://dx.doi.org/10.1007/s10113-0160957-8.

Djouara, H., Belières, J.F., Kébé, D., 2005. Les exploitations agricoles familiales de la zone cotonnière du mali face à la baisse des prix du coton graine. Cahiers Agric. 15, 64-71.

Dorward, A., Chirwa, E., 2011. The Malawi agricultural input subsidy programme: 2005/ 06 to 2008/09. Int. J. Agric. Sustainability 9, 232-247. http://dx.doi.org/10.3763/ ijas.2010.0567.

Enfors, E.I., Gordon, L.J., Peterson, G.D., Bossio, D., 2008. Making investments in dryland development work: participatory scenario planning in the Makanya catchment, Tanzania. Ecol. Soc. 13, 42

FAO, 2006. Guidelines for Soil Description. Food \& Agriculture Organization of the United Nations, Rome.

Falconnier, G.N., Descheemaeker, K., Van Mourik, T.A., Sanogo, O.M., Giller, K.E., 2015. Understanding farm trajectories and development pathways: two decades of change in southern Mali. Agric. Syst. 139, 210-222. http://dx.doi.org/10.1016/j.agsy.2015. 07.005 .

Falconnier, G.N., Descheemaeker, K., Van Mourik, T.A., Giller, K.E., 2016. Unravelling the causes of variability in crop yields and treatment responses for better tailoring of options for sustainable intensification in southern Mali. Field Crops Res. 187, 113-126. http://dx.doi.org/10.1016/j.fcr.2015.12.015.

Falconnier, G.N., Descheemaeker, K., Van Mourik, T.A., Adam, M., Sogoba, B., Giller, K.E., 2017. Co-learning cycles to support the design of innovative farm systems in southern Mali. Eur. J. Agron. 89, 61-74. http://dx.doi.org/10.1016/j.eja.2017.06. 008.

Fine, D., van Wamelen, A., Lund, S., Cabral, A., Taoufiki, M., Dörr, N., Leke, A., Roxburgh, C., Schubert, J., Cook, P., 2012. Africa at Work: Job Creation and Inclusive Growth. 
McKinsey Global Institute, Boston.

Fox, L., Sohnesen, T.P., 2012. Household Enterprises in Sub-Saharan Africa: Why They Matter for Growth, Jobs, and Livelihoods. World Bank, Washington, D.C. http:/ www.afdb.org/fileadmin/uploads/afdb/Documents/Knowledge/Household \%20Enterprise\%20in\%20Sub-Saharan\%20Africa\%20-\%20Why\%20they\%20Matter \%20for\%20Growth\%20Jobs\%20and\%20Livelihoods.pdf.

Frelat, R., Lopez-Ridaura, S., Giller, K.E., Herrero, M., Douxchamps, S., Djurfeldt, A.A., Erenstein, O., Henderson, B., Kassie, M., Paul, B.K., Rigolot, C., Ritzema, R.S., Rodriguez, D., van Asten, P.J.A., van Wijk, M.T., 2016. Drivers of household food availability in sub-Saharan Africa based on big data from small farms. Proc. Natl. Acad. Sci. U. S. A. 113, 458-463. http://dx.doi.org/10.1073/pnas.1518384112.

García-Martínez, A., Bernués, A., Olaizola, A.M., 2011. Simulation of mountain cattle farming system changes under diverse agricultural policies and off-farm labour scenarios. Livestock Sci. 137, 73-86. http://dx.doi.org/10.1016/j.livsci.2010.10.002.

Gibreel, T.M., Herrmann, S., Berkhoff, K., Nuppenau, E.-A., Rinn, A., 2014. Farm types as an interface between an agroeconomical model and CLUE-Naban land change model: application for scenario modelling. Ecol. Indic. 36, 766-778. http://dx.doi.org/10. 1016/j.ecolind.2013.09.009.

Guan, K., Sultan, B., Biasutti, M., Baron, C., Lobell, D.B., 2017. Assessing climate adaptation options and uncertainties for cereal systems in West Africa. Agric. For. Meteorol. 232, 291-305. http://dx.doi.org/10.1016/j.agrformet.2016.07.021.

Harris, D., Orr, A., 2014. Is rainfed agriculture really a pathway from poverty? Agric. Syst. 123, 84-96. http://dx.doi.org/10.1016/j.agsy.2013.09.005

Harris, J.R., Todaro, M.P., 1970. Migration, unemployment and development: a twosector analysis. Am. Econ. Rev. 60, 126-142.

Headey, D.D., Jayne, T.S., 2014. Adaptation to land constraints: is Africa different? Food Policy 48, 18-33. http://dx.doi.org/10.1016/j.foodpol.2014.05.005.

Herrero, M., Thornton, P.K., Bernués, A., Baltenweck, I., Vervoort, J., van de Steeg, J., Makokha, S., van Wijk, M.T., Karanja, S., Rufino, M.C., Staal, S.J., 2014. Exploring future changes in smallholder farming systems by linking socio-economic scenarios with regional and household models. Global Environ. Change 24, 165-182. http:// dx.doi.org/10.1016/j.gloenvcha.2013.12.008.

Hillocks, R.J., 2014. Addressing the yield gap in Sub-Saharan Africa. Outlook Agric. 43, 85-90. http://dx.doi.org/10.5367/oa.2014.0163.

Jayne, T.S., Chamberlin, J., Headey, D.D., 2014. Land pressures, the evolution of farming systems, and development strategies in Africa: a synthesis. Food Policy 48, 1-17. http://dx.doi.org/10.1016/j.foodpol.2014.05.014.

Jolliffe, D., Prydz, E.B., 2016. Estimating international poverty lines from comparable national thresholds. J. Econ. Inequal. 14, 185-198. http://dx.doi.org/10.1007/ s10888-016-9327-5.

Jonckers, D., Colleyn, J.-P., 1974. La communauté familiale chez les Minyanka du Mali. J. Soc. Africanistes 44, 43-52. http://dx.doi.org/10.3406/jafr.1974.1748.

Keating, B.A., Carberry, P.S., Hammer, G.L., Probert, M.E., Robertson, M.J., Holzworth, D., Huth, N.I., Hargreaves, J.N.G., Meinke, H., Hochman, Z., McLean, G., Verburg, K., Snow, V., Dimes, J.P., Silburn, M., Wang, E., Brown, S., Bristow, K.L., Asseng, S., Chapman, S., McCown, R.L., Freebairn, D.M., Smith, C.J., 2003. An overview of APSIM, a model designed for farming systems simulation. Eur. J. Agron. 18, 267-288. http://dx.doi.org/10.1016/S1161-0301(02)00108-9.

Kelly, V., Perakis, S., Diallo, B., Dembéle, N.N., 2010. Cottonseed, Oil, and Cake: CoProducts or By-Products in the C-4 Cotton Sectors? Michigan State University, East Lansing. http://www.fsg.afre.msu.edu/cotton/English_Cottonseed_April2011.pdf.

Kelly, V., Boughton, D., Magen, B., 2011. Cereal Market Dynamics: The Malian Experience from the 1990 to Present. MSU International Development Working Paper.

Laroche Dupraz, C., Postolle, A., 2013. Food sovereignty and agricultural trade policy commitments: how much leeway do West African nations have? Food Policy 38, 115-125. http://dx.doi.org/10.1016/j.foodpol.2012.11.005.

Losh, B., Fréguin-Gresh, S., White, E., 2011. Rural Transformation and Late Developing Countries in a Globalizing World. A Comparative Analysis of Rural Change. Final Report of the RuralStruc Program, Revised Version. World Bank, Washington, DC. http://siteresources.worldbank.org/AFRICAEXT/Resources/2586431323805221801/RuralStruc_final_report_v2_hd.pdf.

Marenya, P., Nkonya, E., Xiong, W., Deustua, J., Kato, E., 2012. Which policy would work better for improved soil fertility management in sub-Saharan Africa, fertilizer subsidies or carbon credits? Agric. Syst. 110, 162-172. http://dx.doi.org/10.1016/j. agsy.2012.04.004

Miguel Ayala, L., van Eupen, M., Zhang, G., Pérez-Soba, M., Martorano, L.G., Lisboa, L.S., Beltrao, N.E., 2016. Impact of agricultural expansion on water footprint in the Amazon under climate change scenarios. Sci. Total Environ. 569, 1159-1173. http:// dx.doi.org/10.1016/j.scitotenv.2016.06.191.

Ministère de la santé et de l'hygiène publique, 2014. PLan d'action national de planification familiale du mali 2014-2018. République du Mali. République du Mali(http:// ec2-54-210-230-186.compute-1.amazonaws.com/wp-content/uploads/2016/05/ Plan-PF-Mali.pdf).

Nubukpo, K., 2011. L'économie politique de la réforme des filières cotonnières d'Afrique de l'Ouest et du centre: vers la convergence des modes d'organisation? Mondes dév 155, 93-109. http://dx.doi.org/10.3917/med.155.0093.

O'Neill, B.C., Kriegler, E., Ebi, K.L., Kemp-Benedict, E., Riahi, K., Rothman, D.S., van Ruijven, B.J., van Vuuren, D.P., Birkmann, J., Kok, K., Levy, M., Solecki, W., 2017. The roads ahead: Narratives for shared socioeconomic pathways describing world futures in the 21st century. Glob. Environ. Change 42, 169-180. http://dx.doi.org/ 10.1016/j.gloenvcha.2015.01.004.

Pachauri, R.K., Mayer, L., 2015. Climate Change 2014: Synthesis Report. In: Intergovernmental Panel on Climate Change (Ed.), Intergovernmental Panel on Climate Change, Geneva, Switzerland.

Painter, T., Sumberg, J., Price, T., 1994. Your terroir and my 'action space': implications of differentiation, mobility and diversification for the approche terroir in Sahelian West Africa. Africa 64, 447. http://dx.doi.org/10.2307/1161368.

Paul, B.K., Frelat, R., Birnholz, C., Ebong, C., Gahigi, A., Groot, J.C.J., Herrero, M. Kagabo, D.M., Notenbaert, A., Vanlauwe, B., van Wijk, M.T., 2017. Agricultural intensification scenarios, household food availability and greenhouse gas emissions in Rwanda: ex-ante impacts and trade-offs. Agric. Syst. http://dx.doi.org/10.1016/j. agsy.2017.02.007. (in press).

Poccard-Chapuis, R., Coulibaly, D., Ba, A., Sissoko, S., Bengaly, M., Coulibaly, J., 2007. Analyse Affinée des Pratiques et des Stratégies Paysannes, Rapport technique, Activité 3, PASE-1. IER, Sikasso, Mali.

Population Council, ICF International, 2015. Mali 2012-13 DHS. Stud. Fam. Plann. 46 227-236. http://dx.doi.org/10.1111/j.1728-4465.2015.00026.x.

Röling, N., 2009. Pathways for impact: scientists' different perspectives on agricultural innovation. Int. J. Agric.Sustainability 7, 83-94. http://dx.doi.org/10.3763/ijas. 2009.0043.

Rajib, M.A., Ahiablame, L., Paul, M., 2016. Modeling the effects of future land use change on water quality under multiple scenarios: a case study of low-input agriculture with hay/pasture production. Sustainability Water Qual. Ecol. 8, 50-66. http://dx.doi. org/10.1016/j.swaqe.2016.09.001.

Ravallion, M., Chen, S., Sangraula, P., 2009. Dollar a day revisited. World Bank Econ. Rev. 23, 163-184. http://dx.doi.org/10.1093/wber/lhp007.

Ripoche, A., Crétenet, M., Corbeels, M., Affholder, F., Naudin, K., Sissoko, F., Douzet, J.M., Tittonell, P., 2015. Cotton as an entry point for soil fertility maintenance and food crop productivity in savannah agroecosystems: evidence from a long-term experiment in southern Mali. Field Crops Res. 177, 37-48. http://dx.doi.org/10.1016/j.fcr. 2015.02.013.

Ritzema, R.S., Frelat, R., Douxchamps, S., Silvestri, S., Rufino, M.C., Herrero, M., Giller, K.E., López-Ridaura, S., Teufel, N., Paul, B.K., Wijk van, M.T., 2017. Is production intensification likely to make farm households food-adequate? A simple food availability analysis across smallholder farming systems from East and West Africa. Food Sec. 9, 115-131. http://dx.doi.org/10.1007/s12571-016-0638-y.

Ronner, E., Franke, A.C., Vanlauwe, B., Dianda, M., Edeh, E., Ukem, B., Bala, A., van Heerwaarden, J., Giller, K.E., 2016. Understanding variability in soybean yield and response to P-fertilizer and rhizobium inoculants on farmers' fields in northern Nigeria. Field Crops Res. 186, 133-145. http://dx.doi.org/10.1016/j.fcr.2015.10. 023.

Samake, A., Belières, J.F., Corniaux, C., Dembele, N., Kelly, V., Marzin, J., Sanogo, O. Staatz, J., 2008. Changements structurels des économies rurales dans la mondialisation. Programme RuralStruc Mali - Phase I. World Bank, Washigton, DC. http://siteresources.worldbank.org/AFRICAEXT/Resources/RURALSTRUC-MALI Phase2.pdf.

Silvie, P.J., Renou, A., Vodounnon, S., Bonni, G., Adegnika, M.O., Héma, O., Prudent, P., Sorèze, J., Ochou, G.O., Togola, M., Badiane, D., Ndour, A., Akantetou, P.K., Ayeva, B., Brévault, T., 2013. Threshold-based interventions for cotton pest control in West Africa: what's up 10 years later? Crop Prot. 43, 157-165. http://dx.doi.org/10.1016/ j.cropro.2012.09.006

Sonobe, T., Akoten, J.E., Otsuka, K., 2009. An exploration into the successful development of the leather-shoe industry in Ethiopia. Rev. Dev. Econ. 13, 719-736. http:// dx.doi.org/10.1111/j.1467-9361.2009.00526.x.

Soumaré, M., Bazile, D., Kouressy, M., Diallo, K., Diakité, C.H., 2008. Diversité agroécosystémique et devenir des céréales traditionnelles au sud du Mali. Cahiers Agric. 17, 79-85.

Stephenne, N., Lambin, E.F., 2004. Scenarios of land-use change in Sudano-sahelian countries of Africa to better understand driving forces. GeoJ 61, 365-379.

Sultan, B., Roudier, P., Quirion, P., Alhassane, A., Muller, B., Dingkuhn, M., Ciais, P., Guimberteau, M., Traore, S., Baron, C., 2013. Assessing climate change impacts on sorghum and millet yields in the Sudanian and Sahelian savannas of West Africa. Environ. Res. Lett. 8, 014040. http://dx.doi.org/10.1088/1748-9326/8/1/014040.

Thompson, J., Scoones, I., 2009. Addressing the dynamics of agri-food systems: an emerging agenda for social science research. Environ. Sci. Policy 12, 386-397. http://dx.doi.org/10.1016/j.envsci.2009.03.001.

Traore, S., Doumbia, A., Traore, V., Tolno, D., 2011. 4ème Recensement General De La Population Et De l'habitat Du Mali (Rgph-2009). INSTAT, Bamako, Mali. http:// www.unfpa-mali.org/sites/default/files/Rapport Etat Structure Version $\% 2022 \% 20$ Dec\%202011.pdf.

Traore, B., Corbeels, M., van Wijk, M.T., Rufino, M.C., Giller, K.E., 2013. Effects of climate variability and climate change on crop production in southern Mali. Eur. J. Agron. 49, 115-125. http://dx.doi.org/10.1016/j.eja.2013.04.004.

Traore, B., Van Wijk, M.T., Descheemaeker, K., Corbeels, M., Rufino, M.C., Giller, K.E., 2015. Climate variability and change in southern Mali: learning from farmer perceptions and on-farm trials. Exp. Agric. 51, 615-634. http://dx.doi.org/10.1017/ S0014479714000507.

Traore, B., Descheemaeker, K., van Wijk, M.T., Corbeels, M., Supit, I., Giller, K.E., 2017. Modelling cereal crops to assess future climate risk for family food self-sufficiency in southern Mali. Field Crops Res. 201, 133-145. http://dx.doi.org/10.1016/j.fcr.2016. 11.002 .

Traore, B., 2014. Climate Change, Climate Variability and Adaptation Options in Smallholder Cropping Systems of the Sudano - Sahel Region in West Africa. Phd Thesis. Wageningen University, Wageningen.

United Nations, 2015. World Population Prospects. Volume I: Comprehensive Tables. United Nations, New York. http://esa.un.org/unpd/wpp/Publications/Files/ WPP2015_Volume-I_Comprehensive-Tables.pdf.

van Ittersum, M.K., Cassman, K.G., Grassini, P., Wolf, J., Tittonell, P., Hochman, Z., 2013 Yield gap analysis with local to global relevance-a review. Field Crops Res. 143, 4-17. http://dx.doi.org/10.1016/j.fcr.2012.09.009. 